\title{
Root-Knot and Root-Lesion Nematode Suppression by Cover Crops, Poultry Litter, and Poultry Litter Compost
}

\author{
K. L. Everts, Department of Natural Resource Science and Landscape Architecture, University of Maryland, Salis- \\ bury 21801, with joint appointment with the University of Delaware, Georgetown 19947; S. Sardanelli, Department \\ of Entomology, University of Maryland, College Park 20742; R. J. Kratochvil, Department of Natural Resource \\ Science and Landscape Architecture, University of Maryland, College Park 20742; D. K. Armentrout, Lower East- \\ ern Shore Research and Education Center, University of Maryland, Salisbury 21801; and L. E. Gallagher, Dorches- \\ ter County Cooperative Extension, University of Maryland, Cambridge 21613
}

\begin{abstract}
Everts, K. L., Sardanelli, S., Kratochvil, R. J., Armentrout, D. K., and Gallagher, L. E. 2006. Root-knot and root-lesion nematode suppression by cover crops, poultry litter, and poultry litter compost. Plant Dis. 90:487-492.

Experiments using soil-incorporated cover crops and amendments of poultry litter (PL) and PL compost to suppress root-knot (RKN) and root-lesion nematodes were conducted in response to increasing nematode populations in Maryland's potato production areas. Identical experiments were established in microplots infested with Meloidogyne incognita or Pratylenchus penetrans. Treatments consisted of 123 -year rotational sequences comprising potato (year 1) and cucumber (year 2) followed by a moderately RKN-resistant or susceptible soybean cultivar, castor bean, grain sorghum, or sorghum sudangrass; PL or PL compost were amended to some of the RKNsusceptible soybean and sorghum sudangrass plots. In the third year of the rotation, potato followed by soybean was planted in all 12 treatments. The RKN-resistant soybean, castor bean, sorghum sudangrass, and fallow or tillage decreased the populations of $M$. incognita compared with microplots where RKN-susceptible soybean had been grown. However, RKN populations quickly recovered. Root-lesion nematode was reduced in the spring of 2001 following application of high rates of PL and PL compost in 2000. In the fall of 2001, sorghum sudangrass alone or in combination with PL or PL compost, grain sorghum, or fallow or tillage reduced rootlesion nematodes compared with either soybean cultivar. No treatment affected root-lesion nematode the following year. The use of cover crops and PL compost is an effective method to reduce nematode populations only if successively incorporated into rotational cropping sequences.
\end{abstract}

Additional keywords: Cucumis sativus, organic amendment, Solanum tuberosum

The southern root-knot nematode, Meloidogyne incognita, ((Kofoid and White, 1919) Chitwood, 1949) is prevalent in Maryland and causes severe damage in areas with sandy soils, which are found predominately on the eastern shore (east of the Chesapeake Bay) and in southern Maryland $(11,26)$. Over the past 20 years, plant and soil samples submitted to the University of Maryland Nematology Laboratory routinely contained economically significant root-knot nematode (RKN) populations. The most prevalent species observed was $M$. incognita, and vegetables were the host plants most frequently encountered. In Maryland, M. incognita has been associated with damage to corn (Zea mays L.), muskmelon (Cucumis melo L.),

Corresponding author: K. L. Everts

E-mail: keverts@umd.edu

Accepted for publication 9 November 2005.

DOI: 10.1094/PD-90-0487

(C) 2006 The American Phytopathological Society soybean (Glycine max (L.) Merr.), sweet potato (Ipomeae batatas L. Lam.), tobacco (Nicotiana tabacum L.), tomato (Lycopersion esculentum Mill.), vetch (Vicia villosa Roth), and wheat (Triticum aestivum L.) (11). Potato (Solanum tuberosum L.), processing cucumber (C. sativus L.), sweet corn, green bean (Phaseolus vulgaris L.), and other vegetables are grown throughout the region and also have experienced significant losses due to RKN.

The root-lesion nematode, Pratylenchus penetrans (Cobb.1917) Chitwood and Oteifa, 1952, also is common in Maryland and Delaware fields (26). P. penetrans can cause severe damage on potato and cucumber. Symptoms of root-lesion nematode infections in potato range from poor crop growth and chlorotic foliage to root cell death resulting from nematode feeding and tubers with scabby or shrunken areas. Yield losses due to $P$. penetrans are highly variable and influenced by environmental conditions and the presence of the fungus Verticillium dahliae.

Growers incur large expenses in controlling root-knot on potato and cucumber. For example, $25 \%$ of the pickling cucumber acreage in Maryland and Delaware was fumigated in 1998, a typical year, to reduce nematode populations (1). In addition, growers often use carbofuran (FMC Corporation, Philadelphia, PA), in large part to manage RKN (1).

Due to the phase-out of methyl bromide and constraints of use of other fumigant nematicides, such as the length of the period following fumigant application when crops cannot be planted, growers have an increased interest in nonchemical control options $(8,20)$. Maryland potato growers met in fall 1999 and expressed interest in cover crops, nonhost rotation crops, and use of poultry manure in the potato cropping system. The growers were especially interested in practices that had been effective, even experimentally, in other regions.

Suppressive cover crops and nematoderesistant rotation crops have reduced nematode population within the soil environment in trials in the United States $(4,5,12,15-19,22,24,25,30,32)$. Some test crops, including rapeseed (Brassica napus L.), limit feeding and reproduction of nematodes (12). Nematode damage (root gall indices) on squash that followed rapeseed was lower than the damage incurred following vetch in 2 of 3 years in Georgia, and similar nematode suppression on potato followed green manure of rapeseed in the Pacific northwest $(4,5,12)$. In one project to evaluate rapeseed cultivars, 'Dwarf Essex' produced the highest total quantity of glucosinolates, which are nematicidal compounds, of four cultivars tested $(6,12,21)$.

Other cover crops also inhibit nematodes. The incorporation of green manures of mustard, clover (Trifolium angustifolium L.), and sorghum sudangrass (Sorghum bicolor (L.) $\times$ S. arundinaceum (Desv.) Stapf var. sudanense (Stapf) Hitchc.) successfully improved control of nematodes in a subsequent potato crop in the northwest United States $(4,5,27)$. The use of switchgrass (Panicum virgatum L.), and other warm-season forage grasses such as sorghum (S. bicolor (L.) Moench), in rotation systems reduced nematode and increased yields of vegetables in the southeastern United States (16-18,24). Final population densities of $M$. incognita but not Pratylen- 
chus spp. were lower on sorghum than on soybean (18). A similar approach using radish (Raphanus sativus L.) and mustard as cover crops resulted in reduction of sugar beet cyst nematode (Heterodera schachtii) in Wyoming $(10,25)$.

Deployment of RKN-resistant crops also has been shown to manage nematodes. Double-cropping of susceptible cucumber and squash following an RKN-resistant pepper resulted in significant reductions in root galling and $M$. incognita reproduction, and increased the number and weight of fruit in South Carolina and Georgia (28). Poultry litter (a mixture of poultry manure and pine shaving bedding) also has been used as an organic soil amendment to suppress RKN and provide an alternative to nematicides $(9,23)$. Breakdown of poultry litter, which stimulates microbial activity in the soil, suppressed nematode damage and population densities $(9,23)$. However, cover crops and poultry litter alone often are only partially effective, or may be less effective under some environmental conditions $(12,15,18,19)$.

The objective of our study was to evaluate the effects of a 3-year rotational cropping system that utilized cover crops and poultry litter (PL) or PL compost amended to soil on populations of $M$. incognita and $P$. penetrans. We focused on treatments that were identified by Maryland growers as economically feasible for their farm operations. A preliminary report of this research has been published (7). A companion field-scale study that examined a limited subset of the treatments we report on here also has been published (14).

\section{MATERIALS AND METHODS}

Microplot procedures, 2000. The experiments were conducted at the University of Maryland's Lower Eastern Shore Research and Education Center (LESREC) in Salisbury. Microplots constructed of cylindrical fiberglass collars $(45 \mathrm{~cm}$ in diameter and $60 \mathrm{~cm}$ deep) inserted into holes dug in soil (Norfolk "A" loamy sand) were filled and planted with three potato cv. Atlantic New Leaf seed pieces on 14 April. (Microplots previously had been fumigated with methyl bromide and subsequently infested with $M$. incognita [cultured on tomato plants, cv. Rutgers, that were planted into the microplots], or with P. penetrans.) Prior to planting, the potato seed pieces were dusted with maneb (1 $\mathrm{kg} / 100 \mathrm{~kg}$ of potato). Weeds were managed with glyphosate (Roundup Ultra at 1.9 liters/ha), S-metolochlor (Dual Magnum at 1.2 liters/ha ), and linuron (Linex $50 \mathrm{DF}$ at $0.9 \mathrm{~kg} / \mathrm{ha})$ on 21 April and sethoxydim (Poast Plus at 1.9 liters/ha ) on 16 June. Fertilizer $(8 \mathrm{~N}-8 \mathrm{P}-16 \mathrm{~K}$ at $58 \mathrm{~kg} / \mathrm{ha})$ was applied on 26 April and 27 June. Potato tubers were harvested and weighed on 12 July. On that same day, samples of three roots, two potato tubers, and $250 \mathrm{~cm}^{3}$ of soil were collected from each plot for vermiform nematode extraction and enumeration. Plots $(n=120)$ with high RKN second-stage infective juvenile (J2) populations were grouped as replicates according to RKN enumeration (Table 1). Replicate 1 comprised the highest RKN numbers and replicate 10 comprised the lowest. Twelve treatments were randomly assigned within each replicate (Table 1). Plots $(n=84)$ with high $P$. penetrans populations also were selected and grouped as seven replicates according to $P$. penetrans enumeration. The same 12 treatments were randomly assigned within these replicates. Glyphosate (Roundup Ultra at 1.9 liters/ha) was applied for weed control prior to cover crop planting. Soil amendments (PL or PL compost) were applied on 15 July (Table 1). PL was applied to fallow plots at $6.7 \mathrm{Mg} / \mathrm{ha}$, a rate used by local growers. Poultry litter was applied at 8.2 or $2.8 \mathrm{Mg} / \mathrm{ha}$ to provide available $\mathrm{N}$ at 168 or $56 \mathrm{~kg} / \mathrm{ha}$, respectively, prior to planting sorghum sudangrass. Soybean Pioneer brand '93B01' plots were amended with PL at $1.1 \mathrm{Mg} / \mathrm{ha}$ to provide available $\mathrm{N}$ at $22 \mathrm{~kg} / \mathrm{ha}$. Likewise, sorghum sudangrass plots were amended with PL at 35.0 or $11.7 \mathrm{Mg} / \mathrm{ha}$ compost to provide available $\mathrm{N}$ at 168 or $56 \mathrm{~kg} / \mathrm{ha}$, respectively, and soybean Pioneer brand 93B01 plots were amended with PL compost at $4.7 \mathrm{Mg} / \mathrm{ha}$ to provide available $\mathrm{N}$ at $22 \mathrm{~kg} / \mathrm{ha}$. Analysis of PL nutrient percent was $3.73 \mathrm{~N}, 0.34 \mathrm{NH}_{4} \mathrm{~N}$, $4.19 \mathrm{P}_{2} \mathrm{O}_{5}, 3.33 \mathrm{~K}_{2} \mathrm{O}, 1.72 \mathrm{Ca}, 1.0 \mathrm{Mg}$, and $0.55 \mathrm{~S}$; and ppm 486.6 Mn, 475.6 Zn, and 553.2 Cu. Analysis of PL compost nutrient percent was $3.32 \mathrm{~N}, 0.68 \mathrm{NH}_{4} \mathrm{~N}, 3.96$ $\mathrm{P}_{2} \mathrm{O}_{5}, 3.31 \mathrm{~K}_{2} \mathrm{O}, 1.61 \mathrm{Ca}, 0.78 \mathrm{Mg}$, and $0.80 \mathrm{~S}$; and ppm 492.6 Mn, 460.5 Zn, and 507.9 $\mathrm{Cu}$. Plots were seeded with soybean (Pioneer brand 93B01, the grower standard, or 'Manokin'), castor bean (Ricinus communis L.) cv. Mall, sorghum sudangrass cv. Green Grazer V, or grain sorghum NK brand 'KS585' on 20 and 21 July. Pioneer brand 93B01 and Manokin are rated as maturity groups III and IVS (late), respectively, and Manokin is resistant to RKN (13). Fallow plots were tilled on 14 August, 5 and 28 September, and 16 October. On 18 and 19 October, soil was sampled, three roots/plot were collected, where available, and soybean biomass was measured. Cover crops were chopped and incorporated into plots. Oat (Avena sativa L.) $(108 \mathrm{~kg} / \mathrm{ha})$ and rapeseed $(10 \mathrm{~kg} / \mathrm{ha})$ were planted on 24 or 27 October in the rootknot or lesion experiment, respectively.

Microplot procedures, 2001. Oat and rapeseed were chopped and incorporated into soil to simulate a disking operation on 18 April. Plots were fertilized (5N-10P$10 \mathrm{~K}$ at $56 \mathrm{~kg} / \mathrm{ha}$ ) on 25 April and 29 May $(34 \mathrm{~N}$ at $56 \mathrm{~kg} / \mathrm{ha})$. Weeds were managed with glyphosate (Roundup Ultra at 1.9 liters/ha) on 29 April. Processing cucumber Asgrow cv. Vlaspik was seeded at 143,320 seed/ha on 1 May. Cucumber beetles (Acalymma vittatum) were managed with esfenvalerate (Asana XL at 512 $\mathrm{ml} / \mathrm{ha}$ ) on 30 May and 19 June. Soil was sampled and the roots of three cucumber

Table 1. Treatments planted in microplots at the University of Maryland's Lower Eastern Shore Research and Education Center, Salisbury during a 3-year cropping-system experiment to determine the effect of cover crop, poultry litter (PL), or PL compost (PLCo) amendment and tillage on populations of Meloidogyne incognita or Pratylenchus penetrans ${ }^{2}$

\begin{tabular}{|c|c|c|c|c|c|c|c|c|c|}
\hline \multicolumn{4}{|l|}{2000} & \multicolumn{4}{|c|}{2001} & \multicolumn{2}{|c|}{2002} \\
\hline Crop 1 & Crop 2 & Amend & Cover & Crop 1 & Crop 2 & Amend & Cover & Crop 1 & Crop 2 \\
\hline Potato & Soybean & None & None & Cucumber & Soybean & None & None & Potato & Soybean \\
\hline Potato & Soybean & PL, $1.1 \mathrm{Mg} / \mathrm{ha}$ & Oat & Cucumber & Soybean & PL, $1.1 \mathrm{Mg} / \mathrm{ha}$ & Oat & Potato & Soybean \\
\hline Potato & Soybean & PLCo, $4.7 \mathrm{Mg} / \mathrm{ha}$ & Oat & Cucumber & Soybean & PLCo, $4.7 \mathrm{Mg} / \mathrm{ha}$ & Oat & Potato & Soybean \\
\hline Potato & Manokin & None & Oat & Cucumber & Manokin & None & Oat & Potato & Manokin \\
\hline Potato & Castor bean & None & Oat & Cucumber & Castor bean & None & Oat & Potato & Soybean \\
\hline Potato & Grain sorghum & None & Oat & Cucumber & Grain sorghum & None & Oat & Potato & Soybean \\
\hline Potato & None & $6.7 \mathrm{Mg} / \mathrm{ha}$ & Oat & Cucumber & None & $\mathrm{PL}, 6.7 \mathrm{Mg} / \mathrm{ha}$ & Oat & Potato & Soybean \\
\hline Potato & Sudangrass & None & Rapeseed & Cucumber & Sudangrass & None & Rapeseed & Potato & Soybean \\
\hline Potato & Sudangrass & $\mathrm{PL}, 8.2 \mathrm{Mg} / \mathrm{ha}$ & Oat & Cucumber & Sudangrass & PL, $8.2 \mathrm{Mg} / \mathrm{ha}$ & Oat & Potato & Soybean \\
\hline Potato & Sudangrass & $\mathrm{PL}, 2.8 \mathrm{Mg} / \mathrm{ha}$ & Oat & Cucumber & Sudangrass & $\mathrm{PL}, 2.8 \mathrm{Mg} / \mathrm{ha}$ & Oat & Potato & Soybean \\
\hline Potato & Sudangrass & PLCo, $35.0 \mathrm{Mg} / \mathrm{ha}$ & Oat & Cucumber & Sudangrass & PLCo, $35.0 \mathrm{Mg} / \mathrm{ha}$ & Oat & Potato & Soybean \\
\hline Potato & Sudangrass & PLCo, $11.7 \mathrm{Mg} / \mathrm{ha}$ & Oat & Cucumber & Sudangrass & PLCo, $11.7 \mathrm{Mg} / \mathrm{ha}$ & Oat & Potato & Soybean \\
\hline
\end{tabular}

${ }^{\mathrm{z}}$ Amend $=$ soil amendment and Cover $=$ winter cover crop. Potato in 2000 was 'Atlantic New Leaf' and in 2002 was 'Atlantic' at three seed pieces/0.16 m²; soybean was Pioneer brand '93B01', unless specified as 'Manokin', at 608,200 seed/ha; cucumber was Asgrow 'Vlaspik' at 182,450 seed/ha; oat was 'Southern States 76-30' at 4,561,290 seed/ha; sudangrass was 'Green Grazer V' at 486,540 seed/ha; grain sorghum was NK brand 'KS585' at 243,270 seed/ha; castor bean was 'Mall' at 60,820 seed/ha; and rapeseed was 'Dwarf Essex' at 2,128,600 seed/ha. 
plants were collected for vermiform extraction, enumeration, and root gall indices evaluation and cucumber fruit were harvested on 27 June.

Soil amendments were applied on 5 July, and soybean, castor bean, sudangrass, and sorghum were seeded on 10 July as described previously. The fallow plots were tilled on 26 July, 16 August, and 5 and 27 September. Soil, root, and plant biomass samples were taken and cover crops were chopped and incorporated on 3 and 4 October. Oat and rapeseed were seeded on 9 October.

Microplot procedures, 2002. Root samples of oat and rapeseed were collected from plots (three to five samples/ microplot) on 11 March. Oat and rapeseed were incorporated on 12 March and $10 \mathrm{~N}$ $10 \mathrm{P}-10 \mathrm{~K}$ at $10 \mathrm{~g} /$ microplot was amended on 15 March. On 16 March, three potato seed pieces were planted in each plot. Weeds were managed as described previously in 2000. Sidedress fertilizer was applied (10N-10P-20K at $10 \mathrm{~g} /$ microplot) on 7 June. Colorado potato beetles Leptinotarsa decemlineata (Say) were managed with spinosad (SpinTor at $438 \mathrm{ml} / \mathrm{ha}$ ) on 11 and 18 June. Vermiform nematode extraction and enumeration was conducted on soil, root, and tubers as described previously and root gall indices evaluation was conducted. Potato tubers were harvested and weighed on 26 and 27 June. Plots received fertilizer amendment $(10 \mathrm{~g}$ of $10 \mathrm{~N}-10 \mathrm{P}-20 \mathrm{~K})$ on 27 June. Soybean was planted to all microplots on 11 July. Weeds were managed with S-metolochlor (Dual Magnum II at 1.2 liters/ha), linuron (Linex $50 \mathrm{DF}$ at $0.8 \mathrm{~kg} / \mathrm{ha}$ ), and glyphosate (Roundup Ultra at 1.9 liters/ha) on 12 July. Glyphosate was applied again on 8 August. Three roots and soil samples were collected for vermiform nematode extraction, enumeration and root gall indices evaluation, and biomass measurement on 9 October.

Laboratory procedures. Each soil sample was mixed thoroughly before re- moving a $250 \mathrm{~cm}^{3}$ subsample for vermiform nematode extraction using a modified Baermann method (3). Extracted vermiforms were collected into a counting dish and plant-parasitic species were identified to genus (using standard morphological characteristics) and enumerated using a sterioscopic microscope $(\times 40)$. Roots were evaluated by washing them and then rating them on the following root galling index (RGI) scale for percent roots galled: $1=$ no galling, $2=1$ to $25,3=26$ to $50,4=51$ to 75 , and $5=76$ to $100 \%$ (2).

Statistical analyses. The number of $M$. incognita $\mathrm{J} 2$ and of $P$. penetrans counted in $250 \mathrm{~cm}^{3}$ of soil was $\log _{10}(x+1)$ transformed to normalize the error variance and accommodate the samples where no nematodes were detected. Log-transformed population counts of $M$. incognita $\mathrm{J} 2$ and $P$. penetrans, the root galling indices, potato and cucumber yield, and soybean biomass were subjected to analyses of variance using Proc Mixed (SAS Institute, Cary, NC). Means were separated where appropriate using Fisher's protected least significant difference test $(P<0.05)$.

\section{RESULTS}

M. incognita. The soybean cv. Manokin, which has moderate resistance to $\mathrm{RKN}$, reduced the population of $M$. incognita $\mathbf{J} 2$ in 2000, 2001, and 2002 compared with plots where the RKN-susceptible soybean cv. Pioneer 93B01 was cropped (Table 2). There was no significant carryover effect of Manokin observed in June of the next crop year (2001 or 2002), although plots that had been planted to RKN-resistant Manokin during 2000 and 2001 had some of the lowest $M$. incognita J2 counts in June 2002 (Table 2). Castor bean also significantly reduced the population of M. incognita J2 in 2000 and 2001 compared with plots where susceptible soybean cultivars were grown. This reduction caused by castor bean was not detected the following springs (June 2001 and 2002). Counts of $M$. incognita $\mathrm{J} 2$ in plots that had sorghum sudangrass chopped and incorporated as green manure ranked among the lowest, but not significantly less than was present in the susceptible soybean in October 2000. In October 2001, these sorghum sudangrass plots had significantly fewer $M$. incognita $\mathrm{J} 2$ compared with the grower standard procedure. Plots of sorghum sudangrass incorporated as a green manure and amended with either PL at $8.2 \mathrm{Mg} / \mathrm{ha}$ or PL compost at 11.7 $\mathrm{Mg} / \mathrm{ha}$ also had significantly fewer $M$. incognita J2 than the RKN-susceptible soybean in October 2001. Fallow plots that were amended with PL at $6.7 \mathrm{Mg} / \mathrm{ha}$ and tilled had dramatically reduced counts of M. incognita $\mathrm{J} 2$ in 2000 and 2001. However, these low populations were rebounding by the following spring (June 2002) and, by October 2002, there was no carryover effect observed for this treatment.

Root gall indices of cucumber varied among treatments in 2001 (Table 3). Cucumber following a previous year's crop of either castor bean or sorghum sudangrass amended with PL at $2.8 \mathrm{Mg} / \mathrm{ha}$ or PL compost at $35 \mathrm{Mg} / \mathrm{ha}$ had significantly less galling than cucumber following the RKNsusceptible soybean standard (Table 3). Root gall indices on potato in 2002 did not differ among treatments. The soybean cv. Manokin sustained significantly less galling than Pioneer brand 93B01 in the fall of 2002. Pioneer brand 93B01 that followed grain sorghum had significantly more galling than where it followed the grower standard treatment or where 93B01 was planted in plots amended with compost at 4.7 Mg/ha.

P. penetrans. There were no significant differences among treatments in the fall of 2000 , when counts of $P$. penetrans, were low overall (Table 4). Throughout the experiment, the soybean Manokin supported root-lesion nematode at populations equal to Pioneer brand 93B01. In spring 2001, significant differences existed among

Table 2. Influence of cover crop, poultry litter (PL), PL compost (PLCo), and tillage on the population of second-stage juveniles of Meloidogyne incognita in a 3-year vegetable rotation at the University of Maryland's Lower Eastern Shore Research and Education Center, Salisbury ${ }^{z}$

\begin{tabular}{|c|c|c|c|c|c|c|c|}
\hline \multirow[b]{2}{*}{ Crop; soil amendment } & \multicolumn{3}{|c|}{2000} & \multicolumn{2}{|c|}{2001} & \multicolumn{2}{|c|}{2002} \\
\hline & 13 April & 12 July & 18 October & 28 June & 3 October & 26 June & 2 October \\
\hline Soybean '93B01'; none & 832 & 1,595 & $399(5.2 \mathrm{ab})$ & 1,123 & $1,426(7.1 \mathrm{a})$ & 516 & $1,599(6.7 \mathrm{~b})$ \\
\hline Soybean 93B01; PL, $1.1 \mathrm{Mg} / \mathrm{ha}$ & 864 & 1,698 & $439(5.4 \mathrm{a})$ & 852 & $1,203(6.9 \mathrm{ab})$ & 1,015 & $2,752(7.5 \mathrm{ab})$ \\
\hline Soybean 93B01; PLCo, $4.7 \mathrm{Mg} / \mathrm{ha}$ & 830 & 1,843 & $238(4.9 \mathrm{abc})$ & 594 & $1,191(6.3 \mathrm{abc})$ & 315 & $1,856(6.7 \mathrm{~b})$ \\
\hline Soybean 'Manokin'; none & 884 & 1,334 & $150(3.6 \mathrm{c})$ & 654 & $247(3.8 \mathrm{de})$ & 124 & $299(4.6 \mathrm{c})$ \\
\hline Castor bean 'Mall'; none & 829 & 1,239 & $50(3.5 \mathrm{c})$ & 395 & $244(3.5 \mathrm{e})$ & 319 & $3,974(7.9 \mathrm{ab})$ \\
\hline Grain sorghum; none & 795 & 1,429 & $437(5.7 \mathrm{a})$ & 412 & $1,087(6.1 \mathrm{abc})$ & 790 & $5,437(8.4 \mathrm{a})$ \\
\hline Fallow; PL, $6.7 \mathrm{Mg} / \mathrm{ha}$ & 888 & 2,716 & $4(0.8 \mathrm{~d})$ & 480 & $4(0.6 \mathrm{f})$ & 247 & $1,808(7.1 \mathrm{ab})$ \\
\hline Sorghum sudangrass; none & 1,008 & 1,604 & $120(3.8 \mathrm{bc})$ & 454 & $584(4.9$ cde $)$ & 393 & $2,587(6.7 \mathrm{~b})$ \\
\hline Sorghum sudangrass; PL, $8.2 \mathrm{Mg} / \mathrm{ha}$ & 831 & 1,443 & $458(5.1 \mathrm{ab})$ & 359 & 567 (5.4 bcd $)$ & 439 & $2,415(6.9 b)$ \\
\hline Sorghum sudangrass; PL, $2.8 \mathrm{Mg} / \mathrm{ha}$ & 864 & 1,789 & $534(5.8 \mathrm{a})$ & 707 & $930(6.2 \mathrm{abc})$ & 841 & $3,813(7.9 \mathrm{ab})$ \\
\hline Sorghum sudangrass; PLCo, $35.0 \mathrm{Mg} / \mathrm{ha}$ & 953 & 1,785 & $576(5.0 \mathrm{ab})$ & 168 & $650(5.9 \mathrm{abc})$ & 113 & $1,811(6.9 \mathrm{~b})$ \\
\hline Sorghum sudangrass; PLCo, $11.7 \mathrm{Mg} / \mathrm{ha}$ & 991 & 1,489 & $610(6.0 \mathrm{a})$ & 316 & 655 (5.4 bcd $)$ & 302 & $1,676(7.0 \mathrm{ab})$ \\
\hline $\operatorname{LSD}(P>\mathrm{F})$ & ns & ns & 0.0001 & ns & 0.0001 & ns & 0.0004 \\
\hline
\end{tabular}

${ }^{\mathrm{z}}$ For description of 3-year vegetable rotation, see Table 1. M. incognita population means from $250 \mathrm{~cm}^{3}$ of soil that comprised three composite subsamples in each of 10 replicate microplots; data were transformed for analyses $\left(\log _{10}[x+1]\right)$; nontransformed data are presented for each sample; where significant differences occurred, the transformed data and significance is reported parenthetically. Means within a column followed by the same letter are not significantly different according to Fisher's protected least significant difference (LSD; $P=0.05)$; ns $=$ no significant difference. 
treatments and the plots amended with high rates of PL (fallow plus PL at 6.7 $\mathrm{Mg} / \mathrm{ha}$ and sorghum sudangrass plus PL at (sorghum sudangrass with PL compost at 35.0 or $11.7 \mathrm{Mg} / \mathrm{ha}$ ) ranked the lowest in $P$. penetrans populations, though not significantly less than the grower standard, RKN-susceptible soybean. Where low rates of PL or PL compost were applied and the RKN-susceptible soybean was planted, $P$. penetrans counts were high. Sorghum sudangrass, planted in plots that were not amended with PL or PL compost, and castor bean and grain sorghum supported root-lesion populations that were not significantly different from those in either Manokin or 93B01 soybean (Table 4).

By October 2001, high $P$. penetrans counts were found where soybean or castor bean were planted (Table 4). Sorghum sudangrass or grain sorghum alone or sor$8.2 \mathrm{Mg} / \mathrm{ha}$ ) and high rates of PL compost

ghum sudangrass in combination with either PL or PL compost had significantly lower $P$. penetrans population than where Pioneer brand 93B01 was planted. Fallow plots, which were amended with PL also had significantly fewer root-lesion nematodes than the plots planted with RKNsusceptible soybean. Treatment effects did not carry over to 2002, where there were no differences in root-lesion nematode in June or October.

Yield. Cucumber and potato yield and soybean plant biomass were variable in microplots infested with $M$. incognita (Table 5). Cucumber fruit yield was significantly greater in microplots that had been planted to castor bean, sorghum sudangrass with a high level of PL ( $8.2 \mathrm{Mg} / \mathrm{ha})$ or PL compost $(35.0 \mathrm{Mg} / \mathrm{ha})$, or fallow amended with PL at $6.7 \mathrm{Mg} / \mathrm{ha}$ than in plots that received the grower standard procedure. Potato yield in 2002 was

Table 3. Impact of cover crops and organic amendments on root galling caused by Meloidogyne incognita as measured by root gall indices (RGI) assessed on cucumber, potato, and soybean plants grown in microplots under a 3 -year vegetable rotation ${ }^{\mathrm{x}}$

\begin{tabular}{lccc}
\hline & & RGI ratingy & \\
\cline { 2 - 4 } Crop; soil amendment & & Potato & Soybean \\
\hline Soybean '93B01'; none & Cucumber & 1.0 & $3.9 \mathrm{bc}$ \\
Soybean 93B01; PL, 1.1 Mg/ha & $4.8 \mathrm{ab}$ & 1.0 & $4.2 \mathrm{abc}$ \\
Soybean 93B01; PLCo, $4.7 \mathrm{Mg} / \mathrm{ha}$ & $4.2 \mathrm{abcd}$ & 1.0 & $3.6 \mathrm{c}$ \\
Soybean 'Manokin'; none & $4.2 \mathrm{bcd}$ & 1.0 & $2.5 \mathrm{~d}$ \\
Castor bean 'Mall'; none & $4.5 \mathrm{abc}$ & 1.0 & $4.3 \mathrm{abc}$ \\
Grain sorghum; none & $4.1 \mathrm{~cd}$ & 1.0 & $5.0 \mathrm{a}$ \\
Fallow; PL, 6.7 Mg/ha & $4.5 \mathrm{abc}$ & 1.0 & $4.3 \mathrm{abc}$ \\
Sorghum sudangrass; none & $4.5 \mathrm{abc}$ & 1.0 & $4.5 \mathrm{abc}$ \\
Sorghum sudangrass; PL, $8.2 \mathrm{Mg} / \mathrm{ha}$ & $4.9 \mathrm{a}$ & 1.0 & $4.9 \mathrm{ab}$ \\
Sorghum sudangrass; PL, $2.8 \mathrm{Mg} / \mathrm{ha}$ & $4.4 \mathrm{abc}$ & 1.0 & $4.4 \mathrm{abc}$ \\
Sorghum sudangrass; PLCo, $35.0 \mathrm{Mg} / \mathrm{ha}$ & $3.7 \mathrm{~d}$ & 1.0 & $4.3 \mathrm{abc}$ \\
Sorghum sudangrass; PLCo, $11.7 \mathrm{Mg} / \mathrm{ha}$ & $4.9 \mathrm{~cd}$ & 1.0 & $4.8 \mathrm{ab}$ \\
LSD $(P>$ F) & 0.043 & $\mathrm{~ns}$ & 0.0006
\end{tabular}

${ }^{\mathrm{x}}$ For description of 3-year vegetable rotation, see Table 1.

y Roots were evaluated by washing them and then rating them on an RGI scale for percent roots galled, where $1=$ no galling, $2=1$ to $25,3=26$ to $50,4=51$ to 75 , and $5=76$ to $100 \%$. Means within a column followed by the same letter are not significantly different according to Fisher's protected least significant difference (LSD; $P=0.05$ ); ns $=$ no significant difference. Cucumber and potato were rated on 28 June 2001 and 2002, respectively, and soybean was rated on 2 October 2002.

${ }^{\mathrm{z}}$ Amendments were poultry litter (PL) or PL compost (PLCo) at the indicated application rates. greater in plots where PL or PL compost had been applied and where soybean was planted the previous year.

Cucumber and potato yield and soybean plant biomass also were variable in microplots infested with $P$. penetrans (Table 6). Cucumber fruit yield in 2001 was significantly greater in plots that followed sorghum sudangrass amended with PL compost at $35.0 \mathrm{Mg} / \mathrm{ha}$ than the grower standard procedure. Yield also was high, but not significantly so, where cucumber followed grain sorghum. In 2002, potato yield was significantly greater compared with the grower standard where potato followed soybean amended with PL compost at $4.7 \mathrm{Mg} / \mathrm{ha}$. No differences in soybean biomass were observed in fall 2002 .

\section{DISCUSSION}

The loss of many nematicides from the market due to environmental concerns and the cost of re-registration have focused attention on the development of alternative methods for managing plant-parasitic nematodes. The impending loss of methyl bromide from the U.S. market has increased the urgency to develop such strategies for susceptible vegetable crops $(8,20,29)$. Crop rotation, planting of resistant cultivars, cover crops, irrigation management, fallow periods, soil amendments, and other cultural procedures all can be used to minimize nematode damage. However, alternative or cover crops that replace another crop in the rotation may reduce income. A loss in income may be offset if nematodes are controlled and fumigation costs are reduced or eliminated. This study was not designed to examine all potential cover crop or manure or manure compost treatments that may suppress nematodes. We focused on treatments (and treatment variations) identified as economically feasible practices by Maryland growers for their farm operations.

Wang and McSorley (31) proposed the suppression of plant-parasitic nematodes

Table 4. Influence of cover crop, poultry litter (PL), PL compost (PLCo), and tillage on populations of Pratylenchus penetrans in a 3-year vegetable rotation at the University of Maryland's Lower Eastern Shore Research and Education Center, Salisbury ${ }^{\mathrm{z}}$

\begin{tabular}{|c|c|c|c|c|c|c|}
\hline \multirow[b]{2}{*}{ Crop; soil amendment } & \multicolumn{2}{|c|}{2000} & \multicolumn{2}{|c|}{2001} & \multicolumn{2}{|c|}{2002} \\
\hline & 13 April & 18 October & 28 June & 3 October & 26 June & 2 October \\
\hline Soybean '93B01'; none & 771 & 33 & 20 (2.0 abcde) & $215(3.6 \mathrm{a})$ & 79 & 280 \\
\hline Soybean 93B01; PL, 1.1 Mg/ha & 865 & 13 & $82(3.6 \mathrm{a})$ & $152(4.3 \mathrm{a})$ & 65 & 297 \\
\hline Soybean 93B01; PLCo, $4.7 \mathrm{Mg} / \mathrm{ha}$ & 730 & 2 & $55(3.2 \mathrm{abc})$ & $208(3.8 \mathrm{a})$ & 127 & 1,716 \\
\hline Soybean 'Manokin'; none & 931 & 267 & $80(3.3 \mathrm{ab})$ & $102(2.5 \mathrm{ab})$ & 18 & 852 \\
\hline Castor bean 'Mall'; none & 882 & 4 & $58(3.2 \mathrm{abcd})$ & $258(4.5 \mathrm{a})$ & 277 & 696 \\
\hline Grain sorghum; none & 1,125 & 7 & $76(3.8 \mathrm{a})$ & $11(1.0 \mathrm{~b})$ & 89 & 218 \\
\hline Fallow; PL, $6.7 \mathrm{Mg} / \mathrm{ha}$ & 1,356 & 9 & $9(1.0 \mathrm{de})$ & $6(0.8 \mathrm{~b})$ & 65 & 407 \\
\hline Sorghum sudangrass; none & 1,077 & 147 & $71(3.0 \mathrm{abc})$ & $13(0.8 \mathrm{~b})$ & 7 & 531 \\
\hline Sorghum sudangrass; PL, $8.2 \mathrm{Mg} / \mathrm{ha}$ & 797 & 6 & 20 (1.1 bcde $)$ & $17(0.7 \mathrm{~b})$ & 2 & 323 \\
\hline Sorghum sudangrass PL, $2.8 \mathrm{Mg} / \mathrm{ha}$ & 951 & 0 & $32(2.7$ abcde $)$ & $7(0.9 \mathrm{~b})$ & 2 & 464 \\
\hline Sorghum sudangrass; PLCo, $35.0 \mathrm{Mg} / \mathrm{ha}$ & 867 & 67 & $3(0.5 \mathrm{e})$ & $50(1.3 \mathrm{~b})$ & 15 & 102 \\
\hline Sorghum sudangrass; PLCo, $11.7 \mathrm{Mg} / \mathrm{ha}$ & 843 & 48 & $18(0.9$ cde $)$ & $4(0.5 \mathrm{~b})$ & 11 & 462 \\
\hline $\operatorname{LSD}(P>F)$ & ns & ns & 0.0222 & 0.0002 & ns & ns \\
\hline
\end{tabular}

${ }^{\mathrm{z}}$ For description of 3-year vegetable rotation, see Table 1. P. penetrans population means of $250 \mathrm{~cm}^{3}$ of soil comprising three composite subsamples in each of seven replicate microplots; data were transformed $\left(\log _{10}[x+1]\right)$ prior to analyses; nontransformed data are presented for each sample date; where significant differences occurred, the transformed data and significance is reported parenthetically. Means within a column followed by the same letter are not significantly different according to Fisher's protected least significant difference (LSD; $P=0.05)$; ns $=$ no significant difference. 
through management of the beneficial free-living nematodes. One goal of their approach is suppression of multiple nematode pests. In Maryland, more than one species of plant-parasitic nematode is present in many fields; therefore, strategies to minimize damage to more than one species also must be developed. In our study, planting an RKN-resistant soybean cultivar or utilizing either castor bean or sorghum sudangrass as cover crops reduced $M$. incognita J2 populations; however, only sorghum sudangrass also reduced $P$. penetrans. Kratochvil et. al. also observed that sorghum sudangrass effectively reduced both RKN and lesion nematode populations in Maryland (14). In fact, sorghum sudangrass incorporated as a green manure reduced the RKN population as effectively as a nematicide application where a susceptible soybean was grown (14). We found the addition of PL or PL compost in combination with a sorghum sudangrass rotation was most effective in reducing populations of $P$. penetrans, although efficacy varied across years. Sorghum sudangrass frequently has reduced Pratylenchus spp. populations in soil; however, the variation in efficacy that we observed also has been observed elsewhere. MacGuidwin and Layne (15) observed no suppression in field trials (in contrast to their earlier greenhouse trials). The difference in results may be due partially to variation in environments, including soil environments that impact microbial or ectoparasitic activity, or the generation of nematicidal compounds in response to organic amendment.

The length of suppression associated with either the cultivar or cover crop and with organic amendments (PL or PL compost) differed in our study. The suppression associated with cultivar or cover crop often was observed only immediately following cultivation of the crop. However, $P$. penetrans suppression associated with $\mathrm{PL}$ or PL compost was observed in June 2001 (i.e., there was a carryover effect). In addition, when sorghum sudangrass was combined with PL (2.8 Mg/ha) or PL compost $(35.0 \mathrm{Mg} / \mathrm{ha})$, root galling was reduced the following spring. This effect was not observed when sorghum sudangrass was grown alone. Therefore, use of sorghum sudangrass in combination with PL may provide longer nematode suppression. In addition, overall suppression of the two nematode species was best achieved by a fall cover crop of sorghum sudangrass with application of PL or PL compost.

The mode of action through which PL or PL compost suppressed $P$. penetrans populations in June 2001 is unknown. Riegel and Noe (23) demonstrated that the addition of PL compost to field soil reduced $M$. incognita numbers and generally increased bacterial and fungal CFU. They hypothesized that increasing microbial populations and their diversity increased the likelihood of the presence of microbes capable of nematode parasitism. Here, we did not observe a reduction in $M$. incognita $\mathrm{J} 2$ population over that observed with amendment of a suppressive sorghum sudangrass cover crop. We did observe suppression of $P$. penetrans in one year where PL compost at $35 \mathrm{Mg} / \mathrm{ha}$ was amended to plots where a sorghum sudangrass cover crop was grown.

Populations of both $M$. incognita $\mathrm{J} 2$ and $P$. penetrans were reduced when soil was fallow, amended with PL, and tilled four times. The addition of organic matter results in many positive changes in soil quality, such as stabilizing soil particles, improving the water-holding capacity, reducing compaction, and improving tilth. Repeated tillage, however, reduces organic matter and will offset many of the benefits of amendment with PL. In addition, tillage may increase sediment loss through runoff and, when PL has been amended, the runoff may contain high phosphorous and nitrogen levels, which are detrimental to water quality, especially in the Chesapeake Bay watershed. Planting PL-amended fields to cover crops and composting PL prior to amendment often will mitigate nutrient loss potential.

The yield response that we observed in this study may have been related to nutrient level, and plots amended with PL or PL compost ranked among the highest in yield or biomass. For example, potato yield in plots where the RKN-susceptible soybean had been grown and amended with PL compost at $4.7 \mathrm{Mg} / \mathrm{ha}$ was among the highest in 2002, even though $M$. incognita or $P$. penetrans populations also were high. Likewise, where sorghum sudangrass had been grown and amended with PL compost at $35 \mathrm{Mg} / \mathrm{ha}$, yields also were high.

Although the combination of sorghum sudangrass and PL or PL compost was one of the best overall treatments, it did not always statistically outperform other

Table 5. Crop yield or vegetative biomass of potato, cucumber, and soybean grown in a 3-year vegetable rotation that included nematode suppressive cover crops, poultry litter (PL), PL compost (PLCo), or tillage in microplots infested with Meloidogyne incognita ${ }^{\mathrm{z}}$

\begin{tabular}{|c|c|c|c|c|}
\hline \multirow[b]{2}{*}{ Crop; soil amendment } & \multirow{2}{*}{$\begin{array}{c}2000 \\
\begin{array}{c}\text { Potato } \\
\text { (kg/plot) }\end{array}\end{array}$} & \multirow{2}{*}{$\begin{array}{c}2001 \\
\begin{array}{c}\text { Cucumber } \\
\text { (kg/plot) }\end{array}\end{array}$} & \multicolumn{2}{|c|}{2002} \\
\hline & & & $\begin{array}{c}\text { Potato } \\
\text { (kg/plot) }\end{array}$ & $\begin{array}{l}\text { Soybean } \\
\text { (kg/plot) }\end{array}$ \\
\hline Soybean '93B01'; none & 0.30 & $0.08 \mathrm{~d}$ & $0.62 \mathrm{ab}$ & 0.14 \\
\hline Soybean 93B01; PL, 1.1 Mg/ha & 0.30 & $0.10 \mathrm{~cd}$ & $0.68 \mathrm{ab}$ & 0.20 \\
\hline Soybean 93B01; PLCo, $4.7 \mathrm{Mg} / \mathrm{ha}$ & 0.38 & $0.11 \mathrm{~cd}$ & $0.72 \mathrm{a}$ & 0.22 \\
\hline Soybean 'Manokin'; none & 0.37 & $0.13 \mathrm{bcd}$ & $0.59 \mathrm{abc}$ & 0.29 \\
\hline Castor bean 'Mall'; none & 0.27 & $0.19 \mathrm{ab}$ & 0.46 cde & 0.25 \\
\hline Grain sorghum; none & 0.33 & $0.08 \mathrm{~d}$ & $0.40 \mathrm{de}$ & 0.22 \\
\hline Fallow; Pl, 6.7 Mg/ha & 0.36 & $0.16 \mathrm{bc}$ & $0.54 \mathrm{bcd}$ & 0.26 \\
\hline Sorghum sudangrass; none & 0.28 & $0.07 \mathrm{~d}$ & $0.35 \mathrm{e}$ & 0.18 \\
\hline Sorghum sudangrass; PL, $8.2 \mathrm{Mg} / \mathrm{ha}$ & 0.28 & $0.16 \mathrm{bc}$ & $0.44 \mathrm{de}$ & 0.20 \\
\hline Sorghum sudangrass PL, $2.8 \mathrm{Mg} / \mathrm{ha}$ & 0.30 & $0.13 \mathrm{bcd}$ & $0.40 \mathrm{de}$ & 0.25 \\
\hline Sorghum sudangrass; PLCo, $35.0 \mathrm{Mg} / \mathrm{ha}$ & 0.29 & $0.23 \mathrm{a}$ & $0.66 \mathrm{ab}$ & 0.24 \\
\hline Sorghum sudangrass; PLCo, $11.7 \mathrm{Mg} / \mathrm{ha}$ & 0.35 & $0.13 \mathrm{bcd}$ & $0.40 \mathrm{de}$ & 0.24 \\
\hline $\operatorname{LSD}(P>F)$ & ns & 0.0001 & 0.0001 & ns \\
\hline
\end{tabular}

${ }^{\mathrm{z}}$ For description of 3-year vegetable rotation, see Table 1. Means within a column followed by the same letter are not significantly different according to Fisher's protected least significant difference (LSD; $P=0.05)$; ns = no significant difference.

Table 6. Crop yield or vegetative biomass of potato, cucumber, and soybean grown in a 3-year vegetable rotation that included nematode suppressive cover crops, poultry litter (PL), PL compost (PLCo), or tillage in microplots infested with Pratylenchus penetrans ${ }^{\mathrm{z}}$

\begin{tabular}{|c|c|c|c|c|}
\hline \multirow[b]{2}{*}{ Crop; soil amendment } & \multirow{2}{*}{$\begin{array}{c}2000 \\
\begin{array}{c}\text { Potato } \\
\text { (kg/plot) }\end{array}\end{array}$} & \multirow{2}{*}{$\begin{array}{c}2001 \\
\begin{array}{c}\text { Cucumber } \\
\text { (kg/plot) }\end{array}\end{array}$} & \multicolumn{2}{|c|}{2002} \\
\hline & & & $\begin{array}{c}\text { Potato } \\
\text { (kg/plot) }\end{array}$ & $\begin{array}{l}\text { Soybean } \\
\text { (kg/plot) }\end{array}$ \\
\hline Soybean '93B01';none & 0.32 & 0.18 bcde & $0.69 \mathrm{bc}$ & 0.22 \\
\hline Soybean 93B01; PL, 1.1 Mg/ha & 0.39 & 0.18 bcde & $0.64 \mathrm{~cd}$ & 0.26 \\
\hline Soybean 93B01; PLCo, $4.7 \mathrm{Mg} / \mathrm{ha}$ & 0.38 & 0.21 abcde & $0.92 \mathrm{a}$ & 0.24 \\
\hline Soybean 'Manokin'; none & 0.38 & 0.17 cde & $0.73 \mathrm{abc}$ & 0.43 \\
\hline Caster bean; none & 0.32 & $0.23 \mathrm{abc}$ & $0.72 \mathrm{abc}$ & 0.32 \\
\hline Grain sorghum; none & 0.41 & $0.26 \mathrm{ab}$ & $0.58 \mathrm{~cd}$ & 0.40 \\
\hline Fallow; PL, $6.7 \mathrm{Mg} / \mathrm{ha}$ & 0.34 & $0.22 \mathrm{abcd}$ & $0.65 \mathrm{bcd}$ & 0.33 \\
\hline Sorghum sudangrass; none & 0.42 & $0.12 \mathrm{e}$ & $0.47 \mathrm{~d}$ & 0.33 \\
\hline Sorghum sudangrass; PL, $8.2 \mathrm{Mg} / \mathrm{ha}$ & 0.41 & 0.19 bcde & $0.70 \mathrm{bc}$ & 0.37 \\
\hline Sorghum sudangrass; PL, $2.8 \mathrm{Mg} / \mathrm{ha}$ & 0.31 & 0.19 bcde & $0.53 \mathrm{~cd}$ & 0.32 \\
\hline Sorghum sudangrass; PLCo, $35.0 \mathrm{Mg} / \mathrm{ha}$ & 0.34 & $0.28 \mathrm{a}$ & $0.86 \mathrm{ab}$ & 0.36 \\
\hline Sorghum sudangrass; PLCo, $11.7 \mathrm{Mg} / \mathrm{ha}$ & 0.39 & 0.14 de & $0.67 \mathrm{bcd}$ & 0.38 \\
\hline $\operatorname{LSD}(P>F)$ & ns & 0.0282 & 0.0046 & ns \\
\hline
\end{tabular}

${ }^{\mathrm{z}}$ For description of 3-year vegetable rotation, see Table 1. Means within a column followed by the same letter are not significantly different according to Fisher's protected least significant difference $(\mathrm{LSD} ; P=0.05) ; \mathrm{ns}=$ no significant difference. 
treatments. In addition, the suppressive effect carried over to the following spring in only 1 year (2001) and only for $P$. penetrans. Spatial distribution, temporal fluctuations in populations, dormancy, the interaction of nematodes with biotic components of the soil ecosystem, and the effect of physical properties of the soil make study of nematode population change difficult. However, in this study, some cover crops, PL, and PL compost suppressed $M$. incognita, $P$. penetrans, or both over a 3-year vegetable crop rotation.

\section{ACKNOWLEDGMENTS}

The research was supported in part by a grant from the United States Department of Agriculture Sustainable Agriculture Research and Education Program LNE 00-131 (USDA 00-C00P-1-8842).

\section{LITERATURE CITED}

1. Beste, C. E., Everts, K. L., and Linduska, J. L. 2001. Pesticide use and practices for processing cucumbers in Maryland and Delaware. J. Veg. Crop Prod. 7(2):33-44.

2. Carter, C. C., and Sasser, J. N. 1982. Research on integrated crop protection system with emphasis on the root-knot nematodes (Meloidogyne spp.) affecting economic food crops in developing nations. North Carolina State University and U.S. Agency for International Development, Raleigh, NC.

3. Christie, J. R., and Perry, V. G. 1951. Removing nematodes from the soil. Proc. Helminthol. Soc. Wash. 18:106-108.

4. Eberlein, C. V., Boydston, R., Al-Khatib, K., Davis, J. R., Guttieri, M. J., Santo, G. S., and Pan, W. 1997. Brassica green manure systems for weed, disease, and nematode control in potatoes. Proc. West. Soc. Weed Sci. 50:24-25.

5. Eberlein, C. V., Guttieri, M. J., Davis, J. R., Boydston, R. A., Miller, T., Libbey, C., and Ak-Khatib, K. 1998. Integrating herbicides and Brassica green manures for weed control in potato. Proc. West. Soc. Weed Sci. 51:81-85.

6. Ettlinger, M. G., and Kjaer, K. 1968. Sulfer compounds in plants. Pages 59-144 in Recent Advances in Phytochemistry. T. J. Mabry, ed. Appleton-Century-Crofts, New York.

7. Everts, K. L., Sardanelli, S., Kratochvil, R. J., and. Armentrout, D. K. 2004. Suppression of root-knot and lesion nematodes by cover crops, poultry litter and compost. (Abstr.) Phytopathology 94:S28.
8. Ferguson, W., and Padula, A. 1994. Economic Effects of Banning Methyl Bromide for Soil Fumigation. United States Department of Agriculture, Washington, DC.

9. Fortnum, B. 1995. Use of poultry litter or manure for root-knot nematode management on vegetables and field crops. Sustainable Agriculture Research and Education (SARE Project Report: AS93-11), Beltsville, MD.

10. Gray, F. A., Koch, D. W., and Krall, J. M. 1997. Comparative field reaction of sugarbeet and several cruciferous crops to Nacobbus $a b$ errans. Nematropica 27:221-227.

11. Jenkins, W. R., Taylor, D. P., Rohde, R. A., and Coursen, B. W. 1957. Nematodes associated with crop plants in Maryland. Univ. Md. AES. Bull. A-89.

12. Johnson, A. W., Golden, A. M., Auld, D. L., and Sumner D. R. 1992. Effects of rapeseed and vetch green manure crops and fallow on nematodes and soil-borne pathogens. J. Nematol. 24(1):117-126.

13. Kenworthy, W. J., Kantzes, J. G., Krusberg, L. R., and Sardanelli, S. 1996. Registration of 'Manokin' soybean. Crop Sci. 36:1079.

14. Kratochvil, R. J., Sardanelli, S., Everts, K. L., and Gallagher, L. E. 2004. Evaluation of crop rotation and other cultural practices for management of root-knot and lesion nematodes. Agron. J. 96:1419-1426.

15. MacGuidwin, A. E., and Layne, T. L. 1995. Response of nematode communities to sudangrass and sorghum-sudangrass hybrids grown as green manure crops. Suppl. J. Nematol. 27(4S): 609-616

16. McSorley, R., Dickson, D. W., and de Brito, J. A. 1994. Host status of selected tropical rotation crops to four populations of root-knot nematodes. Nematropica 24:45-53.

17. McSorley, R., Dickson, D. W., de Brito, J. A., and Hochmuth, R. C. 1994. Tropical rotation crops influence nematode densities and vegetable yields. J. Nematol. 26:308-314.

18. McSorley, R., and Gallaher, R. N. 1993. Population dynamics of plant parasitic nematodes on cover crops of corn and sorghum. J. Nematol. 25(3):446-453.

19. Mojtahedi, H., Santo, G. S., Hang, A. N., and Wilson, J. H. 1991. Suppression of root-knot nematode populations with selected rapeseed cultivars as green manure. J. Nematol. 23(2):170-174.

20. Noling, J. W., and Becker J. O. 1994. The challenge of research and extension to define and implement alternatives to methyl bromide. Suppl. J. Nematol. 26(4S):573-586.
21. Olesen, L. 1981. Glucosinolates. Pages 501 525 in The Biochemistry of Plants, vol. 7. E. E. Conn, ed. Academic Press, New York.

22. Pinkerton, J. N., Santo, G. S., Ponti, R. P., and Wilson, J. H. 1986. Control of Meloidogyne chitwoodi in commercially grown Russet Burbank potatoes. Plant Dis. 70:860-863.

23. Riegel, C., and Noe, J. P. 2000. Chicken litter soil amendment effects on soil borne microbes and Meloidogyne incognita on cotton. Plant Dis. 84:1275-1281.

24. Rodriquez-Kabana, R. Weaver, D. B., Garcia, R., Robertson, D. G., and Carden, E. L. 1998. Bahiagrass for the management of root-knot and cyst nematodes in soybean. Nematropica 19:185-193.

25. Shigaki, T., Gray, F. A., Delaney, R. H., and Koch, D. W. 1998. Evaluation of host resistance and intercropping for management of the northern root-knot nematode in sainfoin, Ono brychis viciifolia. J. Sustain. Agric. 12:23-39.

26. Sinderman, A., Williams, G., Sardanelli, S., and Krusberg, L. R. 1993. Survey for Heterodera glycines in Maryland. J. Nematol. 25:887889.

27. Stark, J. C. 1995. Development of sustainable potato production systems for the Pacific Northwest. Sustainable Agriculture Research and Education, SARE Research Projects, Western Region (SARE, Project Report: LW91-29), Beltsville, MD.

28. Theis, J. A., Davis, R. F., Mueller, J. D., Fery, R.L., Langston, D. B., and Miller, G. 2004 Double-cropping cucumbers and squash after resistant bell pepper for root-knot nematode management. Plant Dis. 88:589-593.

29. United States Department of Agriculture. 1993. Alternatives to methyl bromide: Assessment of research needs and priorities. Proc. U. S. Dep. Agric. Workshop Alternatives to Methyl Bromide, Arlington, VA.

30. Viaene, N. M., and Abawi, G. S. 1998. Management of Meloidogyne hapla on lettuce in organic soil with sudangrass as a cover crop. Plant Dis. 82:945-952.

31. Wang, K., and McSorly, 2005. Effects of soil ecosystem management on nematode pests, nutrient cycling and plant health. APS Net Feature.

32. Zasada, I. A., Ferris, H., Elmore, C. L., Roncoroni, J. A., MacDonald, J. D., Bolkan, L. R. and Yakbe, L. E. 2003. Field application of brassicaceous amendments for control of soilborne pests and pathogens. Online. Plant Health Progress DOI:10.1094/PHP-20031120-01-RS 